\title{
Effect of Tetrodotoxin from Crude Puffer Fish (Tetraodon fluviatilis) Liver Extract on Intracellular Calcium Level and Apoptosis of HeLa Cell Culture
}

Natanael Untario ${ }^{1 *}$, Titik Cinthia Dewi ${ }^{1}$, M Aris Widodo $^{2}$, Pudji Rahaju ${ }^{3}$

${ }^{1}$ Biomedical Science, Medical Faculty, Brawijaya University, Malang, Indonesia

${ }^{2}$ Pharmacology Department, Brawijaya University, Malang, Indonesia

${ }^{3}$ Department Otolaryngology Head and Neck Surgery, Saiful Anwar Public Hospital, Malang, Indonesia

\begin{abstract}
Cervical cancer is the third most commonly diagnosed cancer and fourth leading cause of women death with $8 \%$ of total death caused by cancer in women in 2008. Tetrodotoxin (TTX) is a potent neurotoxin found in inner organs puffer fish, with the specific mechanism of sodium channel blocking, and widely used for research purposes. Previous reports claimed that TTX has the capability of inhibiting metastatic process of cancer and apoptotic effect. Studies also show that apoptosis is a process involving increase of intracellular calcium level, yet the connection between TTX and increase of intracellular calcium level, therefore triggering apoptosis, has not been established. This is an experimental study with post-test only control group design, carried out by exposing HeLa cell culture to crude liver extract of a puffer fish species, Tetraodon fluviatilis. Crude puffer fish liver extract is administered into HeLa cell culture well in different concentrations $10^{-4}, 10^{-2}$, and $10^{-1}$. Intracellular calcium level and apoptosis were then measured after 18 hours of incubation. Measurements of intracellular calcium level were done by using CLSM with Fura-2AM staining, and apoptosis by using flowcytometry with Annexin V/PI. The result shows that there is a significant differences between samples both in intracellular calcium $(\mathrm{p}<0.05)$ and apoptosis $(\mathrm{p}<0,05)$. Both intracellular calcium and apoptosis levels are proportional to liver fish extract concentration. Pearson's correlation test shows correlation between treatment and intracellular calcium levels $(p=0.000)$, between treatment and apoptosis $(\mathrm{p}=0.002)$, but not between intracellular calcium and apoptosis $(\mathrm{p}=0.05)$. These results suggest that TTX induces an increase in intracellular calcium level and apoptosis, but calcium pathway is not the sole cause of the apoptosis.
\end{abstract}

Keywords: Apoptosis, HeLa cell culture, intracellular calcium, Tetraodon fluviatilis, tetrodotoxin

\section{INTRODUCTION}

Cervical cancer is the third most commonly diagnosed cancer and fourth leading cause of women death, contributing to $9 \%(528,000)$ from total new cancer cases per year and $8 \%(257,100)$ total cancer death for women in 2008 [1]. Conventional strategy for cancer management including surgery, radiotherapy, and chemotherapy with both synthetic agents and natural agents have been established for years [2], yet cancer is still the leading cause of death. Side effects of chemotherapy includes headache, hair loss, nausea and vomiting, sore throat, diarrhea, and many more [3]. This clearly calls for other effective therapeutic agents

\footnotetext{
${ }^{*}$ Corresponding author:

Natanael Untario

Biomedical Science, Medical Faculty, Brawijaya University

Jalan Veteran, Malang 65145, Indonesia

E-mail: natanael@untario.com
}

with less intolerable side effects.

Tetrodotoxin (TTX) is a potent neurotoxin found in the inner organs of puffer fish, including Tetraodon fluviatilis. Found in deep water, these fishes are known to be toxic, hence they are are usually returned to the sea by fisherman. TTX is a highly selective voltagegated sodium channel (VGSC) blocker [4]. TTX have been used for anaesthetic agents [5], reducing opioid withdrawal symptoms [6], preventing ischemia in post stroke patients [7]. Recent studies also show that TTX has anti-metastatic [8] and anti tumor properties [9]. Study by Fouda et al. (2005) shows that TTX extracted from masked puffer fish (Arothron diedematus) can

\section{How to cite:}

Untario N, Dewi TC, Widodo MA, Rahaju P (2017) Effect of

Tetrodotoxin from Crude Puffer Fish (Tetraodon fluviatilis)

Liver Extract on Intracellular Calcium Level and Apoptosis

of HeLa Cell Culture. J. Trop. Life. Science 7 (1): 23 - 29. 
induce apoptosis [9]. Connection between apoptosis and increased intracellular calcium level is already wellknown [10], but on how TTX may induce apoptosis is yet to be explained. Therefore, this study investigates the effects of TTX to intracellular calcium level and whether this pathyway is the main contributing factor to TTX-induced apoptosis in tumor cells.

\section{MATERIALS AND METHODS}

This is an experimental study with post-test only control group design. The subject was HeLa cell line culture from cervical cancer. There are 4 groups with 5 repeating samples each, which are 5 samples of HeLa cell culture, 5 samples each of HeLa cell culture exposed to crude $T$. fluviatilis liver extract with concentrations of $10^{-4}, 10^{-2}$, and $10^{-1}$. This research took time from July 2013 until October 2013 at Biomedical Laboratory, Medical Faculty of Brawijaya University, Indonesia.

\section{HeLa cell culture}

HeLa cell line was procured from Badan Pengkajian dan Penerapan Teknologi (BPPT) Serpong, Jakarta, Indonesia. HeLa cells were grown in F12 medium supplemented with L-glutamine and 7\% FBS on tissue-culture plastic in $5 \% \mathrm{CO}_{2}$ incubator at $37^{\circ} \mathrm{C}, 95 \%$ atmosphere, $100 \%$ humidity. After the culture is in monolayer state, crude $T$. fluviatilis liver extract were then added to each well in different concentrations like mentioned above. After the period of $18 \mathrm{~h}$ incubation, cells were then removed and examined.

\section{Extraction of Tetraodon fluviatilis liver}

This method is a modification of TTX extraction method introduced by Zhou et al. In 2003 [11]. The liver was washed then mashed using mortar. Mush were then weighed and added into an Erlenmeyer glass with aquadest equal to $1.5 \times$ tissue weight. Acetic acid was added with concentration $0.2 \%$ tissue weight and then stirred for 1.5 hours in room temperature. Solution was then filtered. Remaining solution was then heated in $80^{\circ} \mathrm{C}$ using water bath for $10 \mathrm{~min}$, and cooled until room temperature. It was then centrifuged at $600 \times \mathrm{g}$ for $10 \mathrm{~min}$. Supernatan then filtered using microfilter $0.2 \mu \mathrm{m}$, and stored at $-4^{\circ} \mathrm{C}$.

\section{Identification of TTX}

(1) Nanodrop spectrophotometry. Solution was prepared by dissolving it in $2 \mathrm{~mL}$ of $2 \mathrm{M} \mathrm{NaOH}$ and heated in boiling water bath for $45 \mathrm{~min}$. After cooling to room temperature, TTX was identified by the UV spectrum for characteristic absorptions associated with C9-base, 2-amino-6-hydroxymethyl-8-hydroxyquinazoline, which are possibly formed from TTX. UV spectrum of alkali-decomposed TTX compounds appears as a shoulder at near $276 \mathrm{~nm}$ [12]. (2) Liquid Chromatography Mass Spectrometry (LC-MSMS). LC-MSMS was performed using TSQ Access Max Type Triple Quadrupole by Thermofisher for the MSMS and Accella type LC and autosampler. $0.1 \%$ Formic acid with aquabidest and $0.1 \%$ formic acid in acetonitrile (90\%, injection volume $2 \mu \mathrm{L}$ ) used as mobile phase. Sample was prepared my diluting $25 \mu \mathrm{L}$ in $1 \mathrm{ml}$ methanol. Ion peak $(\mathrm{M}+\mathrm{H}+)$ appeared at $\mathrm{m} / \mathrm{z}=320$, showing a molecular weight of the toxin (319) [12].

\section{Intracellular Calcium Level Measurement}

HeLa cells were washed 2 times using HBSS, and loaded Fura-2AM by incubation in standard medium containing $5 \mu \mathrm{m}$ acetoxymethyl ester form of fura-2(fura-2-AM) for $30 \mathrm{~min}$ at room temperature $\left(37^{\circ} \mathrm{C}\right)$. Cells were then washed using HBSS twice and resuspensed with density of $2 \times 109$ cells/L. Cells were then incubated for $45 \mathrm{~min}$ at room temperature and mounted in a cell chamber on the stage of Zeiss Axiovert 200 microscope under continuous perfusion. Single-cell fluorescence was excited at $340 \mathrm{~nm}$ and 380 $\mathrm{nm}$ using a Cairn monochromator (100 ms excitation at each wavelength every $2 \mathrm{~s}, 10 \mathrm{~nm}$ bandwidth) and images of the emitted fluorescence obtained with a 40 $\times$ Fluar objective were collected using a 400 DCLP dichroic mirror and a D510/80 emission filter (both from Chroma Technology) and recorded with a Hamamatsu ORCA-ER camera. Single-cell fluorescence was recorded as $340 / 380 \mathrm{~nm}$ fluorescence ratio and calibrated into $\left[\mathrm{Ca}^{2+}\right]$ values off-line as previously described22 using the Metafluor program (Universal Imaging).

\section{Apoptosis measurement}

Apoptosis was measured using flowcytometry Annexin V-FITC kit (Trevigen, Gaithersburg, MD, catalog\# 4830-01-K) staining. Adherent cells released from their substrate using 0.25 trypsin. Cells were collected by centrifugation approximately $300 \times \mathrm{g}$ for 5 to 10 $\mathrm{min}$ at room temperature, then wash in cold $\left(4^{\circ} \mathrm{C}\right)$ phosphate-buffered saline (PBS). Cells were then incubated with $1 \mu \mathrm{L}$ of Annexin-FITC and PI for $15 \mathrm{~min}$ at room temperature, according to manufacturer's instructions. Annexin-FITC/PI-stained samples were diluted in 300 annexin binding buffer and examined immediately using a BD FACSort flow cytometer with 
CellQuest software. Five thousand cells were excited at $488 \mathrm{~nm}$ and examined at 530 and $585 \mathrm{~nm}$ for AnnexinFITC and PI fluorescence, respectively.

\section{Data Analysis}

The data was analyzed using a test of variance (ANOVA) technique with $\mathrm{p}<0.05$. All tests employed SPSS 16 for Windows.

\section{RESULTS AND DISCUSSION}

\section{Identification of TTX in T. Aluviatilis crude liver extract}

Spectrophotometry analysis of $T$. fluviatilis crude liver extract shows a peak around $246 \mathrm{~nm}$ and a shoulder around $276 \mathrm{~nm}$. The shoulder at near $276 \mathrm{~nm}$ is in accordance to the study by Asakawa et al., indicating the formation of C9-base, 2-amino-6-hydroxymethyl-8hydroxyquinazoline specific to TTX or related substances [12]. However, the peak around $246 \mathrm{~nm}$ is not specific to TTX or related substances, and might be due to other substances, considering this is a crude extract (Figure 1).

Spectrophotometry of T. fluviatilis shows a shoulder at near $276 \mathrm{~nm}$ indicating the presence of TTX. Other peak at around $246 \mathrm{~nm}$ shows the presence of other substances other than TTX.

Identification of TTX using LC-MSMS showed predominant peak at $\mathrm{m} / \mathrm{z} 320$, in accordance to TTX molecular weight. Ion transition was found at $302 \mathrm{~m} / \mathrm{z}$ and $257 \mathrm{~m} / \mathrm{z}$ (Figure 2), as assigned to $\left[\mathrm{M}+\mathrm{H}_{2} \mathrm{H}_{2} \mathrm{O}\right]_{+}$, $[\mathrm{M}+\mathrm{H} 3 \mathrm{H} 2 \mathrm{O}]+.12,25$ There are other peaks other than those mentioned, indicating that there are other substances other than TTX in the extract solution.

\section{Effect of T.fluviatilis Crude Liver Extract On Intracellu- lar Calcium and Apoptosis Level of HeLa Cells Culture}

This study showed that intracellular calcium level is in proportion to the concentration of liver extract (sig $<0.05$, ANOVA) (Figure 3, Figure 4). In addition, Pearson's correlation test showed that there was a positive correlation between liver extract concentration and intracellular calcium $(\mathrm{p}=0.000$, Pearson). This means that the higher concentration of liver extract, in which contained TTX, the higher intracellular calcium will be. Regression analysis showed that $79.6 \%$ of intracellular calcium is related to treatment.

Study for apoptosis showed that there was a significant difference between treatment group in terms of apoptosis $(\mathrm{p}<0.05$, ANOVA) and positive correlation between treatment and apoptosis $(\mathrm{p}=0.002$, Pearson $)$ (Figure 3, Figure 5). Again, the higher concentration of liver extract, the higher apoptosis level of HeLa cells culture become. In this case, regression analysis showed that $41.6 \%$ of apoptosis level is related to treatment. In addition, we analyzed whether there was a correlation of intracellular calcium of apoptosis, and the result was none $(p=0.05$, Pearson). There was no correlation between intracellular calcium with apoptosis level of HeLa cells culture.

\section{Culture exposed by different concentration of T. fluvi- atilis crude liver extract}

There is an increase in HeLa cells only (A); HeLa cells + liver extract with $10^{-4}$ concentration (B); HeLa cells + liver extract with $10^{-2}$ concentration (C); HeLa cells + liver extract with $10^{-1}$ concentration (D).

This result confirmed our hypothesis that T.fluviatilis liver extract which contains TTX will trigger an increase in intracellular calcium and apoptosis level. We conclude that calcium increase did contribute to the apoptosis level, but not exclusively, in which many other pathway might played role in the apoptosis process of HeLa cells culture. Hence, apoptosis is a complex, multifactorial, and multi pathway process. This result is in accordance to the study from Fouda saying that TTX has an anti tumor effect, in which he was using crude extract from a different species of puffer fish $A$. diedematus. Fouda confirmed that TTX exposure increase the number of apoptotic cells, using Annexin V staining [9].

Our results also confirmed that $T$. fluviatilis liver extract containing TTX increased intracellular calcium level. This probes to the question as for where those calcium ion came from. Previous study have shown that calcium ion might originated from intracellular and extracellular pool [10].

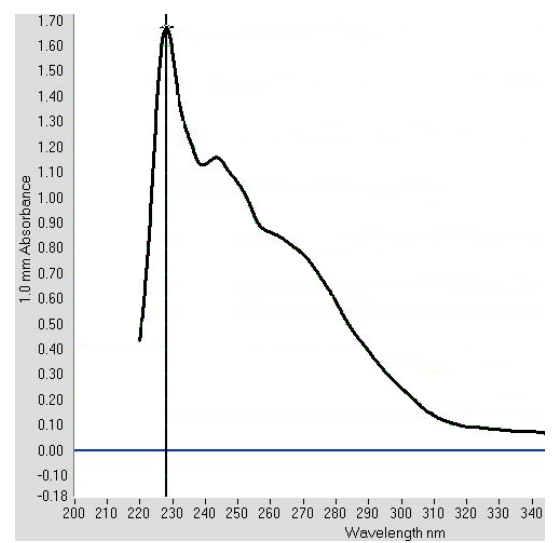

Figure 1. Spectrums of UV absorption of alkaline hydrolyzates of TTX fraction from T. fluviatilis liver extract and authentic TTX with UV spectroscopy nanodrop is around $240 \mathrm{~nm}$ 


\section{Extracellular calcium pool}

Concentration of calcium is higher on the extracellular side than intracellular. Calcium ion influx from extracellular side might come from different channels, which are voltage-gated calcium channels (VGCC), receptor-operated channels (ROC), or store-operated channels (SOC). VGCC is usually activated after depolarization of plasma membrane because of sodium channel influx from extracellular to intracellular side. This activated channels will allow calcium influx, regarding the high concentration gradient of calcium between two sides of plasma membrane [10]. Voltagegated channels conventionally were thought to be exist in excitable cells, but recent study by Chakrabarti in 2006 showed that these channels also exist in non-ex- citable cells, despite the working mechanism in these type of cells has yet to be established [13].

TTX is known for its ability to blocks sodium channel, preventing sodium influx. This action will have 2 effect: (1) depolarization will not happen hence VGCC will not open, preventing calcium influx; (2) low intracellular sodium level, debilitating cancer cells need of sodium ion to function properly, such as the capability to maintain normal cell membrane distribution, a process to hold cells' integrity, hence lowering the capability of cancer cells' proliferation and invasion [14, 15]. Related to the fact that influx of sodium is needed to open VGCC allowing calcium influx, which is supposedly inhibited by TTX treatment, intracellular calcium should be low in the presence of TTX. On the

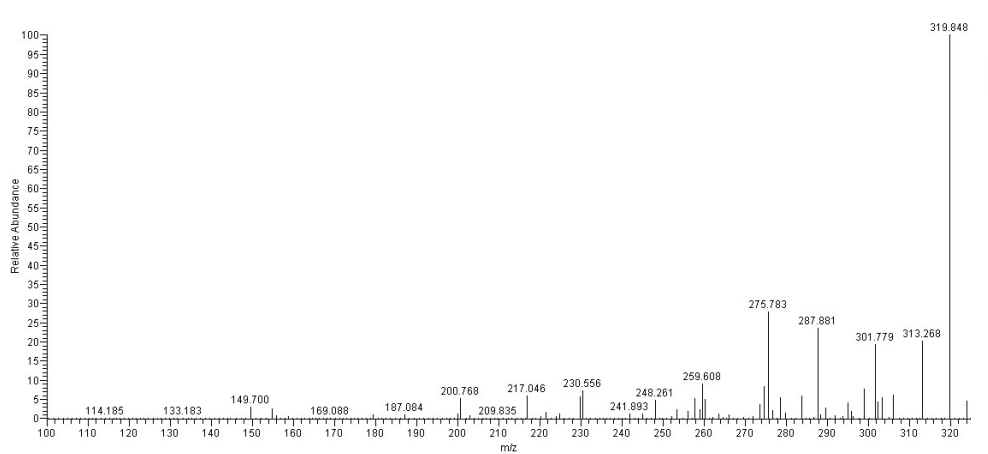

(a)

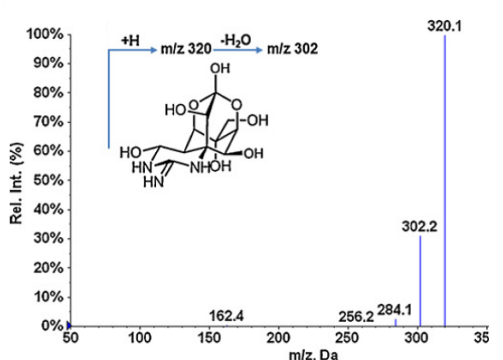

(b)

Figure 2. Product ion mass spectra of with LC-MSMS of T. fluviatilis liver extract (A); Authentic TTX (B) [16]. Predominant peaks showed at m/z 320, in accordance to TTX molecular weight, $302 \mathrm{~m} / \mathrm{z}$ and $257 \mathrm{~m} / \mathrm{z}$ for TTX-related substances. Other peaks indicating presence of other non TTX-related substances.

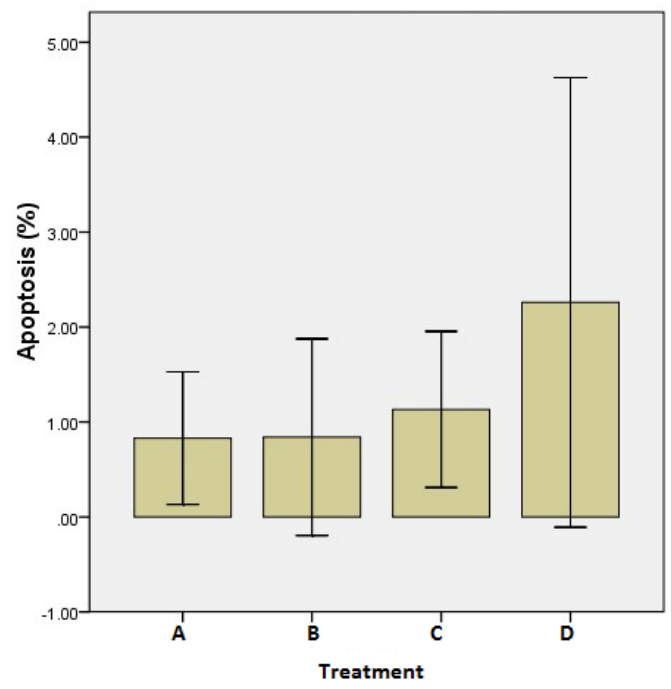

(a)

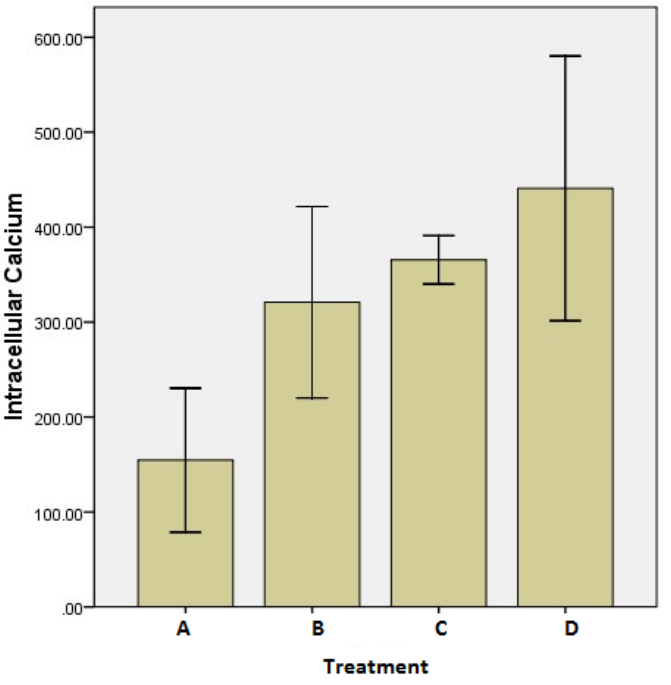

(b)

Figure 3. Mean $\pm \mathrm{SD}$ of apoptosis level (a) and intracellular calcium (b) in HeLa cells culture exposed by different concentration of T. fluviatilis crude liver extract. There is an increase in HeLa cells only (A); HeLa cells + liver extract with $10^{-4}$ concentration (B); HeLa cells + liver extract with $10^{-2}$ concentration (C); HeLa cells + liver extract with $10^{-1}$ concentration (D). 
contrary, our study shows that there is an increase of calcium level. This phenomenon suggests that there are other pathway of VGCC activation which are independent to sodium ion depolarization pathway, that is from cellular potassium efflux [17].

Extracellular calcium influx might also come from activation of ROC, which are mainly mediated by cell membrane receptor, especially glutamate receptor. Binding of glutamate to its receptor will activate and open ROC, allowing calcium influx.10 Another pathway might be from activation of SOC, which are affected by intracellular calcium storage level, specificly by reticulum endoplasma (RE). Decrease of intracellular calcium storage in $\mathrm{RE}$ is mediated by Inositol-1,4,5 triphosphate receptor $(\operatorname{Ins}(1,4,5) \mathrm{P} 3 \mathrm{Rs})$, and ryanodine receptor (RYR). Activation of these two receptor will deplete RE calcium storage to cytoplasm. This relation between calcium storage depletion with calcium influx is known as $\mathrm{Ca}^{2+}$ release-activated $\mathrm{Ca}^{2+}$ current or I(CRAC). Despite all the efforts, signal connecting calcium storage and CRAC channel in plasma membran has yet to be established. Some reports showed that SOC activity is related to transient receptor potential (TRP) channel. In addition, I(CRAC) regulation is thought to be affected by mitochondrial activity. Hence, I(CRAC) is thought to be a dynamic and multifactorial work between RE, mitochondria, and plasma membrane [18].

\section{Intracellular calcium pool}

Intracellular pool source of calcium ion are RE and mitochondria. Depletion of calcium ion storage to cytoplasma is mediated by Ins $(1,4,5) \mathrm{P} 3$ Rs and RYR as explained before. These two receptors were found to be up-regulated in plasma membrane of apoptotic lymphocyte. In cells with deficiency of these receptor, re-

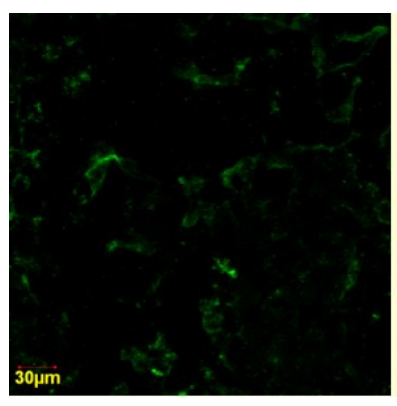

(a)

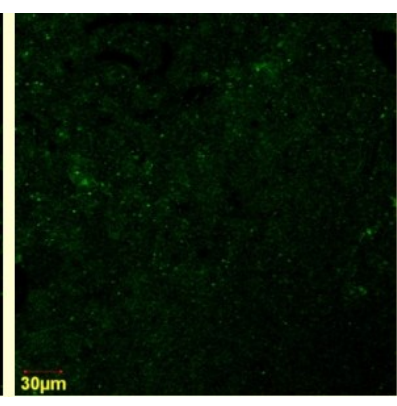

(b)

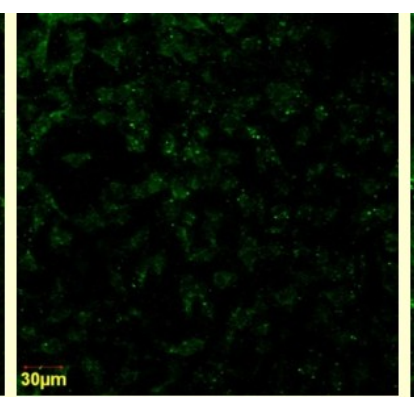

(c)

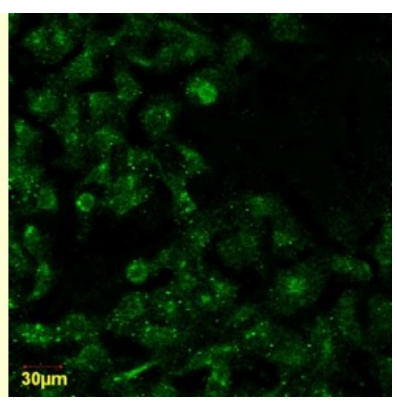

(d)

Figure 4. Identification of intracellular calcium level by confocal laser scanning microscope with Fura-2AM Staining. Green fluorescence shows the color of Fura-2AM. HeLa cells only (A); HeLa cells + liver extract with 10-4 concentration (B); HeLa cells + liver extract with 10-2 concentration (C); HeLa cells + liver extract with 10-1 concentration (D)

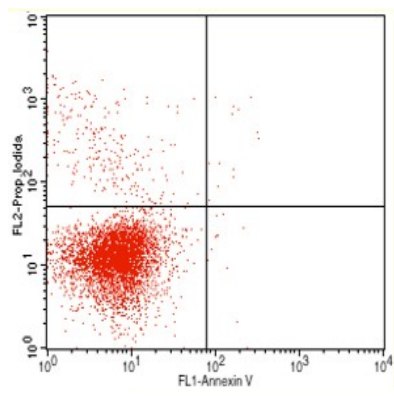

(a)

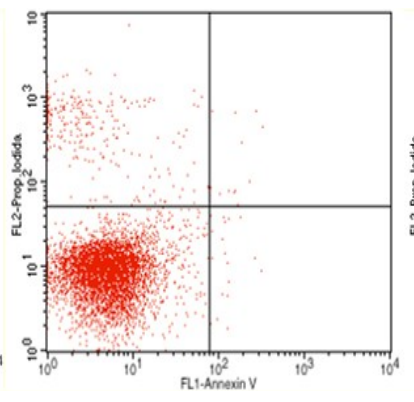

(b)

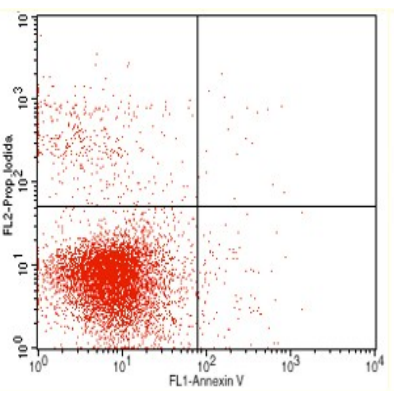

(c)

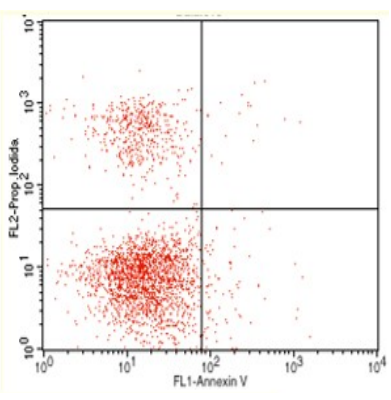

(d)

Figure 5. Identification of apoptosis using flowcytometry with Annexin V/PI Staining. Lower left (Annexin -/PI -): viable cells; upper left (Annexin -/PI +): necrotic cells; lower right (Annexin +/PI -): early apoptotic cells; upper right (Annexin +/PI +): late apoptotic cells. HeLa cells only (A); HeLa cells + liver extract with 10-4 concentration (B); HeLa cells + liver extract with 10-2 concentration (C); HeLa cells + liver extract with 10-1 concentration (D). 
sistancy to apoptosis were found, which can be reverted pharmacologically by increasing cytoplasmic calcium level [10]. Mitochondria is involved in intracellular calcium compartementalization. Mitochondrial uptake of calcium from cytoplasma is done via uniport transporter, and can be released from multiple route such as uniporter reversion, $\mathrm{Na}^{+} \mathrm{H}^{+}$-dependent- $\mathrm{Ca}^{2+}$ exchange, or formation of permeable transition pore (PTP).

Mitochondria is a calcium buffer, but overload of calcium intake by mitochondria will trigger apoptosis via intrinsic pathway. Calcium ion play role in activating $\mathrm{Bcl}-2$ protein via dephosphorilation, catalized by calcineurin. Calcium also trigger an increase in outer mitochondrial membrane (OMM) and pro-apoptotic mitochondrial protein release. This permeability transition requires a pore complex, known as PTP between two mitochondrial membrane. This mitochondrial innermembrane space (IMS) contains pro-apoptotic factors such as cytochrome $\mathrm{C}$, apoptosis inducing factor (AIF), procaspase-9, Smac/DIABLO, and endonuclease $\mathrm{G}[19,20,21,22]$.

PTP is an important point of apoptosis which can be activated not only by calcium overload, but also other mitochondrial stress, such as reactive oxygen species (ROS), and high cellular $\mathrm{pH}$. These factors will activate PTP and pro-apoptotic protein to cytoplasma, altogether with apoptotic protease activating factor 1, cleaves procaspase- 9 to become caspase- 9 , and so the apoptosis cascade begins [23]. This theory is supported by study showing that TTX is able to trigger ROS formation [24]. Both ROS and calcium are mayor inducer of PTP mitochondrial formation [25].

\section{CONCLUSION}

T. fluviatilis crude liver extract containing TTX triggered an increase in intracellular calcium and apoptosis level of HeLa cells culture, but apoptosis is not exclusively caused by increased intracellular calcium. As for the origin of intracellular calcium increase level still needs further research to define whether it came from extracellular or intracellular pool.

\section{ACKNOWLEDGMENT}

This work was supported by Research Development Foundation of Medical Faculty, Brawijaya University, Malang, Indonesia.

\section{REFERENCES}

1. Ferlay J, Shin HR, Bray F et al. (2010) Estimates of worldwide burden of cancer in 2008: GLOBOCAN 2008. Inter- national Journal of Cancer 127: 2893-2917.

2. Gupta A, Mazumder UK, Kumar RS, Kumar TS (2004) Anti-tumor activity and anti-oxident role of Bauhinia racemosa against Ehrlich ascites carcinoma in Swiss albino mice. Acta Pharmacologica Sinica 25 (8): 1070-1076.

3. X-Plain (2011) Patient education: Chemoterapy. http://online.x-plain.com/. Accessed: March 2015.

4. Benzer TI (2007) Toxicity, Tetrodotoxin. http://emedicine.medscape.com/. Accessed: March 2015.

5. Hagen NA, Fisher KM, Lapointe B et al. (2007) An openlabel, multi-dose efficacy and safety study of intramuscular tetrodotoxin in patients with severe cancer-related pain. Journal of Pain Symptom Manage 34 (2): 171-182.

6. Madhavan A, He L, Stuber GD et al. (2010) Micro-Opioid receptor endocytosis prevents adaptations in ventral tegmental area GABA transmission induced during naloxone-precipitated morphine withdrawal. The Journal of Neuroscience 30 (9): 3276-3286.

7. Zhao X, Yeh JZ, Narahashi T (2001) Post-stroke dementia. Nootropic drug modulation of neuronal nicotinic acetylcholine receptors. Annals of the New York Academy of Sciences 939: 179-186

8. Brackenbury W, Djamgoz M (2007) Nerve growth factor enhances voltage-gated $\mathrm{Na}^{+}$channel activity and Transwell migration in Mat-LyLu rat prostate cancer cell line. Journal of Cell Physiology 210 (3): 602-608.

9. Fouda FM (2005) Anti-tumor activity of tetrodotoxin extracted from the Masked Puffer fish Arothron diadematus. Egyptian Journal of Biology 7:1-13.

10. Orrenius S, Zhivotovsky B, Nicotera P (2003) Regulation of cell death: The calcium-apoptosis link. Nature Publisihing 4 (7): 552-565.

11. Zhou M, Shum FHK (2003) Method of extracting tetrodotoxin. https://www.google.com/patents/US6552191 Accessed: January 2015.

12. Asakawa M, Shida Y, Miyazawa K, Naguchi T (2012) Chromatography - The most versatile method of chemical analysis, Dr. Leonardo Calderon (Ed.), InTech. http://www.intechopen.com/books/chromatography-themost-versatile-method-of-chemical-analysis/instrumentalanalysis-of-tetrodotoxin. Accessed: February 2015. doi: 10.5772/48668.

13. Chakrabarti $R$, Chakrabarti $R$ (2006) Calcium signaling in non-excitable cells: $\mathrm{Ca}^{2+}$ release and influx are independent events linked to two plasma membrane $\mathrm{Ca}^{2+}$ entry channels. Journal of Cellular Biochemistry 99 (6): 15031516.

14. Bragadeeswaran S, Therasa D, Prabhu K, Kathiresan K (2010) Biomedical and pharmacological potential of tetrodotoxin-producing bacteria isolated from marine pufferfish Arothron hispidus (Muller, 1841). The Journal 
of Venomous Animals and Toxins including Tropical Diseases 16 (3): 421-431. doi: 10.1590/S167891992010000300008.

15. Abd El-Dayem SM, Fouda FM, Ali EH, Abd El Motelp BA (2012) The antitumor effects of tetrodotoxin and/or doxorubicin on Ehrlich Ascites carcinoma-bearing female mice. Toxicology and Industrial Health 29 (5): 404-417. doi: $10.1177 / 0748233711434955$

16. Rusnak M, Tóth ZE, House SB, Gainer H (2007) Depolarization and neurotransmitter regulation of vasopressin gene expression in the rat suprachiasmatic nucleus in vitro. The Journal of Neuroscience 27 (1): 141-151. doi: 10.1523/JNEUROSCI.3739-06.2007

17. Ferri KF, Kroemer G (2001) Organelle-specific initiation of cell death pathways. Nature Cell Biology 3 (11): E255E263.

18. Martinou JC, Desagher S, Antonsson B (2000) Cytochrome $\mathrm{c}$ release from mitochondria: all or nothing. $\mathrm{Na}$ ture Cell Biology 2 (3): E41-E43.

19. Joza N, Susin SA, Daugas E et al. (2001) Essential role of the mitochondrial apoptosis-inducing factor in pro- grammed cell death. Nature 410 (6828): 549-554.

20. Verhagen AM, Ekert PG, Pakusch M et al. (2000) Identification of DIABLO, a mammalian protein that promotes apoptosis by binding to and antagonizing IAP proteins. Cell 102 (1): 43-53.

21. Parrish J, Li L, Klotz K et al. (2001) Mitochondrial endonuclease $\mathrm{G}$ is important for apoptosis in C. elegans. Nature 412 (6842): 90-94. doi: 10.1038/35083608.

22. Hengartner MO (1998) Apoptosis: Death cycle and Swiss army knives. Nature 391: 441-442. doi:10.1038/35036

23. Abd El-Motelp BA, Zaazaa AM (2013) Potential antitumor effect of tetrodotoxin and/or quercetin against ehrlich carcinoma in mice. World Journal of Pharmacy and Pharmaceutical Sciences 2 (6): 6653-6667.

24. Tanaka T, Nangaku M, Miyata T et al. (2004) Blockade of calcium influx through L-type calcium channels attenuates mitochondrial injury and apoptosis in hypoxic renal tubular cells. Journal of the American Society of Nephrology 15 (9): 2320-2333. doi: 10.1097/01.ASN.0000138287.468 49.82 